\title{
Crohn's disease - genetic factors and progress of the disease
}

\author{
Tomas Kupka ${ }^{\mathrm{a}, \mathrm{b}}$, Jarmila Simova ${ }^{\mathrm{b}, \mathrm{c}}$, Jana Dvorackova ${ }^{\mathrm{b}, \mathrm{d}}$, Lubomir Martinek ${ }^{\mathrm{b}, \mathrm{e}}$, Oldrich Motyka ${ }^{\mathrm{f}}$, Magdalena Uvirova ${ }^{\mathrm{b}, \mathrm{c}}$, \\ Petr Dite ${ }^{a, b}$
}

\begin{abstract}
Background and Objectives. Crohn's disease is a multifactorial inflammatory disease affecting mainly the gastrointestinal tract. The genetic factors that are involved in the disease include mainly three mutations of the gene NOD2/ CARD15 (R702W, G908R, 3020insC). The aim of this study was to determine the relationship between the presence of these variants and disease phenotype.

Material and Methods. 70 patients with Crohn's disease were examined for the presence of the above-mentioned mutations. The researchers used the medical records to retrospectively obtain clinical data and together with the information obtained prospectively according to the protocol they analysed the connection between gene mutations and disease phenotype.

Results. At least one mutation was found in 22 patients with Crohn's disease (32\%), four patients were found to have two different mutations (composed heterozygotes - $6 \%$ ) and six patients $(9 \%)$ were homozygotes for the 3020insC gene. No significant differences were found between the groups with wild-type form and the mutated form of the NOD2 / CARD15 gene with respect to age at the time of diagnosis, form of the disease or localization according to the Montreal classification.

Conclusion. Mutations of the NOD2 / CARD15 gene did not significantly affect the frequency of reoperations, homozygotes with 3020ins C gene mutations, however, represented a high risk group. The phenotype was not related significantly to the presence of the examined mutations.
\end{abstract}

Key words: Crohn's disease, NOD/CARD15, Montreal classification

Received: September 4, 2017; Accepted with revision: December 19, 2017; Available online: January 18, 2018 https://doi.org/10.5507/bp.2017.058

${ }^{a}$ Department of Internal Medicine, University Hospital Ostrava, Czech Republic

${ }^{b}$ Faculty of Medicine, University of Ostrava, Czech Republic

'CGB laborator, a.s., Laboratory of Molecular Genetics and Pathology, Ostrava, Czech Republic

dInstitute of Clinical Pathology, University Hospital Ostrava, Czech Republic

${ }^{e}$ Clinic of Surgery, University Hospital Ostrava, Czech Republic

${ }^{f}$ Department of Inorganic Analysis, Centre of Nanotechnology, VSB - Technical University of Ostrava, Czech Republic

Corresponding author: Tomas Kupka, e-mail: tomas.kupka@fno.cz

\section{INTRODUCTION}

Together with ulcerative colitis, Crohn's disease is the main representative of inflammatory bowel disease (IBD). Crohn's disease is a relapsing inflammatory disease affecting mainly the gastrointestinal tract. The pathogenesis is multifactorial, involving both environmental and genetic factors. Most patients develop purely inflammatory symptoms at first but many of them will eventually develop intestinal fibrosis, which can lead to severe complications, such as stenosis of intestinal lumen, or intestinal fistula. The number of patients who develop stenosing or fistulising complications varies. The rate of disease progression seems to be unpredictable, although many attempts have been made to define "aggressive phenotype"1,2. The objective of the prediction of phenotype is to identify patients at high risk of developing severe disease who could benefit from early aggressive therapy. Mass familial occurrence has been known for more than 70 years and extensive studies of twins in northern Europe have suggested the contribution of a genetic component. Based on genome-wide studies and meta-analyzes the researchers identified at least 70 chromosomal loci that exhibit reference to the development of Crohn's disease ${ }^{2-4}$. In 2001, two groups independently first published the association of polymorphisms / variants in the NOD2 (nucleotidebinding oligomerization domain 2) gene, also known as CARD15 (caspase recruitment domain 15) with increased likelihood of developing Crohn's disease ${ }^{5,6}$. NOD2 gene is located on chromosome 16 (16q12) and encodes a protein belonging to the family of Nod2-like receptors. Three variants of the NOD2 gene are associated with Crohn's disease including two single nucleotide substitutions of p.R702W p.G908R which lead to a change of the amino acid sequence of NOD2 protein, and single base insertion of cytosine in the sequence of NOD2 gene p.L1007fs (also known as c.3019_3020insC or 1007fs) resulting in a stop-codon and the truncated protein. It is reported that these three variants represent approximately $81 \%$ of mutations in the NOD2 gene in patients with CD and that the relative risk of the development of Crohn's disease compared to a healthy population is 2-4 times higher in the carriers of one of sequence variants in the NOD2 gene (heterozygotes) and up to approximately 17 times higher 
in carriers of two variants (homozygotes, composed heterozygotes) ( ref. $\left.^{7-10}\right)$.

The aim of this study was to determine the relation between genetic mutations associated in Crohn's disease with disease activity, treatment, complications, prognosis and the need for surgical intervention.

\section{MATERIAL AND METHODS}

The researchers approached 120 patients who have been diagnosed with Crohn's disease in the past, based on conventional clinical, radiologic, endoscopic and histological examination methods and who signed informed consent. Data were obtained retrospectively from medical records and prospectively completed with the required information from the protocol of the study. It is therefore a retrospective-prospective study. Obtained data include sex, age at diagnosis, duration and character of the problems, extra intestinal manifestations, previous therapy, necessity for surgery, endoscopic finding, Montreal classification and newly added laboratory tests including genetic test to identify mutations in NOD2/CARD15 - R702W, G908R, 3020insC ( ref. $^{11}$ ).

70 patients met the criteria for inclusion in the study, patients with incomplete data were excluded from the analysis. 38 women (54\%) and 32 men (46\%) were included. All patients were taken a $5 \mathrm{ml}$ peripheral blood sample collected in the sampling system with $\mathrm{K}_{3}$-EDTA for testing three major mutations in NOD2/CARD15 gene. The method for detecting specified mutations was the amplification of target regions of the gene NOD2 / CARD15 located on chromosome $16 \mathrm{q} 12$ by polymerase chain reac- tion (PCR) and subsequent digestion of PCR products with restriction enzymes and separation of the resulting fragments in polyacrylamide gel. The patients with mutation (24 patients) were those with at least one mutation in one of the three analyse variants. Clinical examinations were blinded in relation to the genetic testing.

The results were statistically evaluated using the goodness of fit test (Pearson chi-square test) and where appropriate, Fisher's exact test, if the frequencies identified in certain combinations were too low for the chi-square test to be used. A graphical representation of the identified associations was performed using mosaic graphs. All statistical evaluation was performed in the program $\mathrm{R}$ environment (R Core Team (2014). R: A language and environment for statistical computing. R Foundation for Statistical Computing, Vienna, Austria. URL http:// www.R-project.org/).

\section{RESULTS}

70 patients fulfilled the inclusion criteria. The average age of patients was 34 years (standard deviation \pm 11 , median 33 years, range $18-70$ years), the average age at diagnosis 23 years (range 5-55 years). The number of unoperated patients was $22(32 \%)$, once operated patients were $25(35 \%)$, repeatedly operated patients were 23 (33\%).

22 patients (32\%) with established Crohn's disease were found positive for at least one mutation monitored, four patients $(6 \%)$ were composed heterozygotes and six patients (9\%) homozygotes for the 3020insC gene.

We found that there is no difference at the age of diagnosis between patients with specific mutation and without

Table 1. Clinical characteristics of patients with Crohn's disease generally and with respect to the presence of NOD2/CARD15 mutations.

\begin{tabular}{|c|c|c|c|}
\hline & All $(n=70)$ & $\begin{array}{c}\text { Any NOD2 mutation } \\
(\mathrm{n}=22)\end{array}$ & $\begin{array}{l}\text { Without mutation } \\
(\mathrm{n}=48)\end{array}$ \\
\hline Men/women & $32 / 38$ & $7 / 15$ & $25 / 23$ \\
\hline age & $34 \pm 11$ & & \\
\hline \multicolumn{4}{|c|}{ Age according to the Montreal classification (number, \%) } \\
\hline A1 & $18(25.7)$ & $6(8.6)$ & $12(17.1)$ \\
\hline $\mathrm{A} 2$ & $48(68.6)$ & $15(21.4)$ & $33(47.1)$ \\
\hline A3 & $4(5.7)$ & $1(1.4)$ & $3(4.3)$ \\
\hline \multicolumn{4}{|c|}{ Localization according to the Montreal classification (number, \%) } \\
\hline L1 & $40(57.1)$ & $10(14.3)$ & $30(42.9)$ \\
\hline $\mathrm{L} 2$ & $12(17.1)$ & $4(5.7)$ & $8(11.4)$ \\
\hline L3 & $18(25.7)$ & $8(11.4)$ & $10(14.3)$ \\
\hline $\mathrm{L} 4$ & $0(0)$ & $0(0)$ & $0(0)$ \\
\hline \multicolumn{4}{|c|}{ Behaviour according to the Montreal classification (number, \%) } \\
\hline B1 & $44(62.9)$ & $12(17.1)$ & $32(45.7)$ \\
\hline B2 & $25(35.7)$ & $9(12.9)$ & $16(22.9)$ \\
\hline B3 & $1(1.4)$ & $1(1.4)$ & $0(0)$ \\
\hline $\mathrm{P}$ & $10(14.3)$ & $5(7.1)$ & $5(7.1)$ \\
\hline AZA $(\%)$ & $18(25.7)$ & $4(5.7)$ & $14(20.0)$ \\
\hline Biological treatment $(\%)$ & $24(34.3)$ & $10(14.3)$ & $14(20.0)$ \\
\hline Surgery $1 \mathrm{x}(\%)$ & $25(35.7)$ & $4(5.7)$ & $21(30.0)$ \\
\hline Reoperation (\%) & $23(32.9)$ & $4(5.7)$ & $19(27.1)$ \\
\hline
\end{tabular}


Table 2. NOD2 genotype in patients with Crohn's disease.

\begin{tabular}{|c|c|c|c|c|c|c|c|c|}
\hline \multicolumn{9}{|c|}{ NOD2 genotype } \\
\hline \multicolumn{3}{|c|}{ R702W (number, \%) } & \multicolumn{3}{|c|}{ G908R (number, \%) } & \multicolumn{3}{|c|}{ 3020insC (number, \%) } \\
\hline heterozygote & homozygote & wild-type & heterozygote & homozygote & wild-type & heterozygote & homozygote & wild-type \\
\hline $4(5.7)$ & $0(0)$ & $66(94.3)$ & $4(5.7)$ & $0(0)$ & $66(94.3)$ & $12(17.1)$ & $6(8.6)$ & $52(74.3)$ \\
\hline
\end{tabular}

it (or with any mutations and without any mutation). The share of patients who (had not) undergone any / elective / emergency surgery was different in patients with R702W mutation and in patients without this mutation. This effect was most pronounced in urgent surgery - while patients without the mutation were the least represented category, these cases were the most frequent in patients with mutation (Goodness fit test, $P=0.02171$ ).

\section{DISCUSSION}

IBD aetiology is still poorly understood, but it is increasingly accepted that the pathogenesis is facilitated by dysregulation of the immune response to commensal flora in genetically susceptible individuals. The greatest discovery in the field of pathogenesis of IBD in the last decade in Caucasians suffering from Crohn's disease was identification of NOD2/CARD15 polymorphisms ${ }^{5,6}$.

The increased incidence of IBD may be associated with changes in lifestyle. This suggestion is in line with earlier studies that showed that urbanization is an important risk factor in the development of IBD. Soon et al. demonstrated that life in urban society was positively associated with the development of IBD (ref. ${ }^{12}$ ).

According to the literature, approximately 30-50\% of patients with Crohn's disease from Western Europe and North America carry at least one of the variants in the NOD2 gene (it is said that $10-30 \%$ of patients with Crohn's disease are heterozygous - carriers of one of the three sequence variants in NOD2 gene and 3-15\% of patients with Crohn's disease are homozygotes or composed heterozygotes - carriers of two variants) (ref. ${ }^{13,14}$ ). In the Nordic countries, generally characterized by homogeneous population, the frequency of mutations is lower than in the European population ${ }^{15,16}$ and in some Asian ethnicities no variations in the NOD2 was found at all ${ }^{17,18}$. These findings point to the ethnic and geographical variations that can affect the differences in the frequency of development of Crohn's disease and the presence of NOD2 gene variants in different world populations ${ }^{19}$. Earlier Czech results confirmed at least one mutation in NOD2 in $46 \%$ of patients with Crohn's disease and $21 \%$ in the controls ${ }^{20}$.

The presence of the mutations may cause accelerated and more aggressive progression of the disease because the impaired immune response is unable to adequately cope with the penetration of bacteria and because the mutation itself encourages excessive immune response. Mutation of 3020 insC is a frameshift of mutations leading to a reduction of protein in the area with a leucine rich repeat (LRR), which is the main area that is involved in immunological regulations, which may explain why the mutation of 3020ins C leads to a more aggressive disease progression in comparison with the other two mutations ${ }^{21}$. NOD2/CARD15 protein stimulates the secretion of defensin through bacterial muramyl dipeptide. Defensin levels in patients with Crohn's disease and mutations is significantly reduced ${ }^{22}$.

Helio et al. ${ }^{15}$ showed that the NOD2 gene variants were associated with ileal affections and stricturing and a penetrating form of the disease. Other studies also support the opinion of the significant conjunction of mutations with ileal localization of disease, and some show a lack of localization in the colon. Barreiro et al. ${ }^{19}$ demonstrated that in the Gallic population, the need for surgical interventions due to Crohn's disease is higher in carriers of G908R and 3020insC. Vavassori et al. ${ }^{23}$ showed that mutation of $3020 \mathrm{ins} C$ in an Italian population is a risk factor for Crohn's disease. Radlmayer et al. ${ }^{24}$ observed a positive association of mutation of cytosine insertion with fistulising or fibrostenosing subtype of Crohn's disease.

An Australian study noted that patients with mutations in contrast to patients without them are subject to more frequent surgeries. These findings were particularly significant in the presence of 3020insC $\left(\right.$ ref. $^{21}$ ).

A Spanish study found that mutations in the NOD2/ $C A R D 15$ are a predictive risk factor for surgical intervention needs due to stricturing affection ${ }^{25}$.

Other studies in Central Europe have confirmed the increased probability for surgical intervention ${ }^{26}$, but they found no association of NOD2 mutations with outbreak of the disease at a younger age, isolated ileal disabilities, complicated disease (B2 or B3 under the Montreal classification), as mentioned in some earlier works by other authors $^{19,22,27}$.

The presence of two mutations in NOD2 (either homozygous or compound heterozygous) have a higher degree of specificity for the aggressive phenotype ${ }^{28}$.

A systematic review from 2009 included 18727 cases and 17102 controls examined whether NOD2 mutations were equally important risk factors for Crohn disease. The results showed markedly higher risk of Crohn disease for $3020 \mathrm{insC}$ and revealed the risks of Crohn disease for compound heterozygotes and homozygotes to be similar and markedly higher than for simple heterozygotes ${ }^{29}$.

One paper that examined the prevalence and genotype-phenotype analysis of NOD2 mutations in Polish and Bosnian populations showed that the risk for Crohn disease is increased in patients with NOD2 mutations in Poland and especially homozygous NOD2 mutations in Poland and Bosnia. The presence of variant NOD2 alleles was associated with increased need for surgery and reduced incidence of perianal disease ${ }^{30}$.

A German study from 2010 investigated the relation- 
ship of NOD2 mutations to disease manifestation and the risk of surgery in a cohort of childhood-onset CD patients. NOD2 mutations were highly associated with $\mathrm{CD}$ and stricturing behavior, with the 3020 insC mutation also conferring a risk for isolated ileal disease. The authors found a significant association between the need for surgery and NOD2 carrier status and surgery occurrence at an earlier stage of disease in children with 3020insC mutations ${ }^{31}$.

At least one of the monitored mutations was found in our group of 22 patients with Crohn's disease, which indicates the presence of the mutation in $32 \%$ of the patients studied. This result corresponds to the lower limit of the indicated range, but is $14 \%$ lower than the previous result of another facility in the Czech Republic. We found a trend towards an increased representation of ileal involvement as in other European studies but the results were not statistically significant. An important limitation of the study is that the patient samples were small, and thus an important link between genotype and phenotype was not detected.

\section{CONCLUSION}

Genetics plays one of the most important roles in the development of Crohn's disease and the study of genetic variants associated with Crohn's disease contributes to understanding the pathophysiology. Expression of the disease phenotype is also influenced by a number of environmental factors. To determine the overall phenotype of the disease, it is therefore necessary to apply a multifactorial approach that includes environmental factors, genetic factors, exposure to different medications, smoking, first symptoms of the disease, etc. If there was a precise disease severity prediction method, it would have a significant benefit for the patient and medical care.

The ability to predict the natural development of the disease in high-risk patients may be useful when applying top-down therapy that can prevent complications and positively alter the development of the disease ${ }^{32,33}$.

It would be useful to analyze whether the mutations in the NOD2 / CARD15 are able to predict response to treatment, especially biological. We currently have no mutations in the NOD2 / CARD15 that would predict which patients after infliximab treatment, would stay in remission and which would suffer an early relapse ${ }^{34}$.

There is considerable optimism that genotyping of NOD2 / CARD15 mutations could be used in the development of clinical models for treating Crohn's disease, particularly in determining the aggressive treatment or surgical interventions after diagnosis of Crohn's disease ${ }^{21}$.

Understanding the influence of genetic factors on the course of Crohn's disease may be facilitated by a prospective multicenter study with a large number of patients.

Acknowledgment: Financial support front he grant project SGS024/LF/2014-2015 of the Faculty of Medicine, University of Ostrava, is gratefully acknowledged.
Authors contributions: TK: collecting data (gastroenterological); LM: collecting data (surgical); JS, MU: genetic evaluation; JD: histological assessments; OM: statistical analysis; PD: supervision, coordination.

Conflict of interest statement: The authors state that there is no conflict of interest regarding the publication of this article.

\section{REFERENCES}

1. Louis E, Collard A, Oger AF, Degroote E, Aboul Nasr El Yafi FA, Belaiche J. Behaviour of Crohn's disease according to the Vienna classification: changing pattern over the course of the disease. Gut 2001;49:77782.

2. Beaugerie L, Seksik P, Nion-Larmurier I, Gendre JP, Cosnes J. Predictors of Crohn's disease. Gastroenterology 2006;130:650-6.

3. Lakatos L, Mester G, Erdelyi Z, Balogh M, Szipocs I, Kamaras G, Lakatos PL. Striking elevation in incidence and prevalence of inflammatory bowel disease in a province of western Hungary between 1977-2001. World J Gastroenterol 2004;10:404-9.

4. Franke A, McGovern DP, Barrett JC, Wang K, Radford-Smith GL, Ahmad T, Lees CW, Balschun T, Lee J, Roberts R, Anderson CA, Bis JC, Bumpstead S, Ellinghaus D, Festen EM, Georges M, Green T, Haritunians T, Jostins L, Latiano A, Mathew CG, Montgomery GW, Prescott NJ, Raychaudhuri S, Rotter Jl, Schumm P, Sharma Y, Simms LA, Taylor KD, Whiteman D, Wijmenga C, Baldassano RN, Barclay M, Bayless TM, Brand S, Büning C, Cohen A, Colombel JF, Cottone M, Stronati L, Denson T, De Vos M, D'Inca R, Dubinsky M, Edwards C, Florin T, Franchimont D, Gearry R, Glas J, Van Gossum A, Guthery SL, Halfvarson J, Verspaget HW, Hugot JP, Karban A, Laukens D, Lawrance I, Lemann M, Levine A, Libioulle C, Louis E, Mowat C, Newman W, Panés J, Phillips A, Proctor DD, Regueiro M, Russell R, Rutgeerts P, Sanderson J, Sans M, Seibold F, Steinhart AH, Stokkers PC, Torkvist L, Kullak-Ublick G, Wilson D, Walters T, Targan SR, Brant SR, Rioux JD, D'Amato M, Weersma RK, Kugathasan S, Griffiths AM, Mansfield JC, Vermeire S, Duerr RH, Silverberg MS, Satsangi J, Schreiber S, Cho JH, Annese V, Hakonarson H, Daly MJ, Parkes M. Genome-wide meta-Analysis increases to 71 the number of confirmed Crohn's disease Susceptibility loci. Nat Genet 2010;42:1118-25.

5. Hugot JP, Chamaillard M, Zouali H, Lesage S, Cezard JP, Belaiche J, Almer S, Tysk C, O'Morain CA, Gassull M, Binder V, Finkel Y, Cortot A, Modigliani R, Laurent-Puig P, Gower-Rousseau C, Macry J, Colombel JF, Sahbatou M, Thomas G. Association of NOD2 leucine-rich repeat variants with susceptibility to Crohn's disease. Nature 2001;411:599603.

6. Ogura Y, Bonen DK, Inohara N, Nicolae DL, Chen FF, Ramos R, Britton H, Moran T, Karaliuskas R, Duerr RH, Achkar JP, Brant SR, Bayless TM, Kirschner BS, Hanauer SB, Nunez G, Cho JH. A frameshift mutation in NOD2 associated with susceptibility to Crohn's disease. Nature 2001;411:603-6.

7. Derakhshan F, Naderi N, Farnood A, Firouzi F, Habibi M, Detvany MR, Javeri A, Bahari A, Balaii H, Rad MG, Aghazadeh R, Zali MR. Frequency of three common mutations of CARD15/NOD2 gene in Iranian IBD patiens. Indian J Gastroenterol 2008;27:8-11.

8. Hugot JP, Zaccaria I, Cavanaugh J, Yang H, Vermeire S, Lappalainen M, Schreiber S, Annese V, Jewell DP, Fowler EV, Brant SR, Silverberg MS, Cho J, Rioux JD, Satsangi J, Parkes M; for the IBD International Genetics Consortium. Prevalence of CARD15/NOD2 mutations in Caucasian healthy people. Am J Gastroenterol 2007102(6):1259-67.

9. Lesage S, Zouali H, Cezard JP. CARD15/NOD2 mutational analysis and genotype-phenotype correlation in 612 patients with inflammatory bowel disease. Am J Hum Genet 2002;70:845-57.

10. Economou M, Trikalinos TA, Loizou KT, Tsianos EV, loannidis JP. Differential effects of NOD2 variants on Crohn's diesease risk and phenotype in diverse populations: metaanalysis. Am J Gastroenterol 2004;99:2393-404.

11. Kupka T, Simova J, Martinek L, Svoboda P, Klvana $P$, Bojkova M, Uvirova M, Dovrtelova L, Dite P. Crohnova nemoc - geneticke faktory z pohledu etiopatogeneze. Vnitrni lekarstvi 60(7-8):635-9. (In Czech) 
12. Soon IS, Molodecky NA, Rabi DM, Ghali WA, Barkema HW, Kaplan GG. The relationship between urban environment and the inflammatory bowel diseases: a systematic review and metaanalysis. BMC Gastroenterol 2012;12:51.

13. Henckaerts L, Vermeire S. NOD2/CARD15 disease associations other than Crohn's disease. Infl amm Bowel Dis 2007;13(2):235-41.

14. Brant SR,Wang MH, Rawsthorne $P$, Sargent $M$, Wu Datta L, Nouvet $F$, Shugart YY, Bernstein CN. A Population-Based Case-Control Study of CARD15 and Other Risk Factors in Crohn's Disease and Ulcerative Colitis Am J Gastroenterol 2007;102(2):313-23.

15. Helio T, Halme L, Lappalainen M, Fodstad H, Paavola-Sakki P, Turunen U, Farkkila M, Krusius T, Kontula K. CARD15/NOD2 gene variants are associated with familially occurring and complicated forms of Crohn's disease. Gut 2003;52:558-62.

16. Torkvist L, Noble CL, Lordal M, Sjoqvist U, LindForss U, Nimmo E R, Russell R K, Lofberg R, Satsangi J. Contribution of CARD15 variants in determining susceptibility to Crohn's disease in Sweden. Scand J Gastroenterol 2006;41:700-5.

17. Leong, RW, Armuzzi A, Ahmad T, Wong ML, Tse P, Jewell DP,Sung JJ. NOD2/CARD15 gene polymorphisms and Crohn's disease in the Chinese population. Aliment Pharmacol Ther 2003;17:1465-70.

18. Inoue N, Tamura K, Kinouchi Y, Fukuda Y, Takahashi S, Ogura Y, Inohara N, Nunez G, Kishi Y, Koike Y, Shimosegawa T, Shimovama T, Hibi T. Lack of common NOD2 variants in Japanese patients with Crohn's disease. Gastroenterology 2002;123:86-91.

19. Barreiro-de-Acosta M, Mendoza JL, Lana R, Dominguez-Mu-oz JE, Diaz-Rubio M. NOD2/CARD15: geographic differences in the Spanish population and clinical applications in Crohn's disease. Rev Esp Enferm Dig 2010;102:321-6.

20. Hradsky O, Lenicek M, Dusatkova P, Bronsky J, Nevoral J, Valtrova V, Kotalova R, Szitanyi P, Petro R, Starzykova V. Variants of CARD15, TNFA and PTPN22 and susceptibility to Crohn's disease in the Czech population: high frequency of the CARD15 1007fs. Tissue antigens 2008;71:538-47.

21. Bhullar M, Macrae F, Brown G, Smith M, Sharpe K. Prediction of Crohn's disease aggression through NOD2/CARD15 gene sequencing in an Australian cohort. World J Gastroenterol 2014;20(17):500816.

22. Long $W Y$, Chen $L$, Zhang CL, Nong RM, Lin MJ, Zhan LL, Lv XP. Association between NOD2/CARD15 gene polymorphisms and Crohn's disease in Chinese Zhuang patients. World J Gastroenterol 2014;20:4737-44.

23. Vavassori P, Borgiani P, Biancone L, D'Apice M R, Blanco Gdel V, Vallo L, De Nigris F, Monteleone I, Monteleone G, Pallone F, Novelli G. CARD15 mutation analysis in an Italian population: Leu1007fsinsC but neither Arg702Trp nor Gly908Arg mutations are associated with Crohn's disease. Inflamm Bowel Dis 2004;10:116-21.

24. Radlmayr M, Torok HP, Martin K, Folwaczny C. The c-insertion mutation of the NOD2 gene is associated with fistulizing and fibrostenotic phenotypes in Crohn's disease. Gastroenterology 2002;122:2091-2.

25. Alvarez-Lobos M, Arostegui J, Sans M, Tassies D, Plaza S, Delgado S Lacy AM, Pique JM, Yagüe J, Panés J. Crohn's disease patients carrying Nod2/CARD15 gene variants have an increased and early need for first surgery due to stricturing disease and higher rate of surgical recurrence. Ann Surg 2005;242:693-700.

26. Martinek L, Kupka T, Simova J, Klvana P, Bojkova M, Uvirova M, Zonca, P. NOD2/CARD15 mutations and the risk of reoperation in patients with Crohns disease. Rozhl Chir 2015;94(6):242-6.

27. Lauriola M, Ugolini G, Rivetti S, Nani S, Rosati G, Zanotti S, Montroni I, Manaresi A, Zattoni D, Belluzzi A, Castellani L, D'Uva G, Mattei G, Taffurelli M, Strippoli P, Solmi R. IL23R, NOD2/CARD15, ATG16L1 and $\mathrm{PHOX} 2 \mathrm{~B}$ polymorphisms in a group of patients with Crohn's disease and correlation with sub-phenotypes. Int J Mol Med 2011;27:469-77.

28. Adler J, Rangwalla SC, Dwamena BA, Higgins PD. The prognostic power of the NOD2 genotype for complicated Crohn's disease: a meta-analysis. Am J Gastroenterol 2011;106:699-712.

29. Yazdanyar S, Weischer M, Nordestgaard BG. Genotyping for NOD2 Genetic Variants and Crohn Disease: a Metaanalysis. Clinical Chemistry Nov 2009;55(11):1950-7.

30. Salkic NN, Adler G, Zawada I, Alibegovic E, Karakiewicz B, KozlowskaWiechowska A, Wasilewicz M, Sulzyc-Bielicka V, Bielickiet D. NOD2/ CARD 15 mutations in Polish and Bosnian populations with and without Crohn's disease: prevalence and genotype-phenotype analysis Bosn J Basic Med Sci 2015;15(2):67-72.

31. Ballauff $A, C$ aßen $M$, Helmbrecht J, Hubertus J, Hartl D, Koletzko S, Kappler R, Lacher M, Lohse P, Schroepf S, Schweinitz DV, Uhlig $\mathrm{HH}$. NOD2 mutations predict the risk for surgery in pediatric-onset Crohn's disease. J Pediatr Surg 2010;45(8):1591-7.

32. Oldenburg B, Hommes D. Biological therapies in inflammatory bowel disease: top-down or bottom-up? Curr Opin Gastroenterol 2007;23:395-9.

33. Nasir BF, Griffiths LR, Nasir A, Roberts R, Barclay M, Gearry RB, Lea RA. An envirogenomic signature is associated with risk of IBD-related surgery in a population-based Crohn's disease cohort. J Gastrointest Surg 2013;17:1643-50.

34. Lu C, Waugh A, Bailey RJ, Cherry R, Dieleman LA, Gramlich L, Matic K, Millan M, Kroeker KI, Sadowski D, Teshima CW, Todoruk D, Wong C, Wong K, Fedorak RN. Crohn's disease genotypes of patients in remission vs relapses after infliximab discontinuation. World J Gastroenterol 2012;18:5058-64. 